\title{
Piracy: The Pre-existing Security Problem at Antiquity
}

\author{
Korsanlık: Antikçă̆ın Öncelikli Güvenlik Sorunu
}

\begin{abstract}
Murat ARSLAN*
Abstract: When the historical references concerning the pre-existing security problem of the activities of pirates and the Anatolian Mediterranean coast are examined, the subject is seen to be presented by the ancient historians, geographers and poets in a way in which each repeats and summarizes the other. Therefore, through looking at the way the issue was handled and narrated in the ancient sources and its methodology, it is possible to determine how they were influenced by each other and to what extent they are similar. In the modern literature, this situation can also be observed in the references that are listed successively in almost the same order, mostly chronologically, in the footnotes on this subject. In fact, in the course of the historical perspective (longue durée) it is true that piracy has a romantic and timeless dimension that attracts the academician. The effects of this situation can be understood in Turkey, especially since the 2000's, when studies on piracy emerged with a sudden enthusiasm and as a result of the popular trend and became the reason for a series of articles that followed and repeated one another. When the ancient sources and modern literature mentioned in the same way are carefully analyzed, it is seen that another point that has not been clarified in detail until now has been repeated with an interesting emphasis. This is hidden in the fact that the 'uncanny' topography, in which the pirates commonly dwelt, has not been investigated in a versatile manner from the site landscape archaeological perspective. The historical geographical and contextual context associated with the activity of piracy, which was the pre-existing security problem of the Anatolian Mediterranean in antiquity, constitutes the general framework of this current study.
\end{abstract}

\section{Keywords: Piracy, Eastern Mediterranean, Security Problem, Antiquity}

Öz: Anadolu Akdenizi’nin öncelikli güvenlik sorununa ilişkin tarihsel referanslar incelendiğinde konunun antikçağ tarihçileri, coğrafyacıları ve şairleri tarafından korsanlık faaliyetleri çerçevesinde birbirini tekrar eder ve özetler şekilde sunulduğu görülür. Bu sebeple, meselenin antik kaynaklarda ele alınış ve hikaye ediliş şekli ile metodolojisine bakıldığında bunların birbirlerinden ne yönde etkilendikleri ve ne derecede benzeştiklerini tespit etmek mümkündür. Modern literatürde ise bu durum, konuya ilişkin verilen dipnotlarda neredeyse aynı düzende, çoğunlukla kronolojik olarak, birbiri ardına sıralanan referanslarda da izlenebilir. Aslına bakılırsa korsanlığın, tarihsel perspektif süreci içinde (longue durée) akademisyeni kendine çeken, romantik ve eskimeyen bir boyutu olduğu doğrudur. Bu durumun etkileri ülkemizde de, özellikle 2000'li yıllardan itibaren korsanlıkla ilgili çalışmaların ani bir hevesle ve popüler akımın sonucu olarak patlak vermesinden ve birbirini takip ve tekrar eden bir dizi makale furyasına gerekçe olmasından anlaşılabilir. Aynı şekilde anılan antik kaynaklar ve modern literatür dikkatli bir biçimde analiz edildiğinde bugüne değin ayrıntılı şekilde açığa kavuşturulmamış bir başka noktanın ilgi çekici bir vurguyla tekrarlandığı gözlenir. Bu da korsanların yaygın biçimde ikamet ettikleri 'tekinsiz’ topoğrafyanın, alan arkeolojisi peyzajı perspektifinden çok yönlü araştırılmamış olmasında gizlidir. Antikçağda Anadolu Akdenizi'nin öncelikli güvenlik sorunu olan korsanlık faaliyetleriyle bağlantılı tarihsel coğrafi ve içeriksel bağlam halihazırdaki bu çalışmanın genel çerçevesini oluşturmaktadır.

Anahtar sözcükler: Korsanlık, Doğu Akdeniz, Güvenlik Sorunları, Antikçă̆

\footnotetext{
* Prof. Dr., Akdeniz Üniversitesi, Edebiyat Fakültesi, Tarih Bölümü, Antalya, marslan@akdeniz.edu.tr, https://orcid.org/0000-0003-1132-7423
} 
In order to understand piracy in antiquity, it is necessary to look at the myth, history and anthropological dimension that created it as well as the socio-economic structure of the period. Piracy, which was the pre-existing security problem of the Anatolian Mediterranean; is directly related to the strategic location and history of the region on the coasts of the main sea trade route in a spatial sense, as well as the mythological, cultural, historical, geographical, ethnographic and etymological elements that it contains. When the mythological stories concerning the Anatolian Mediterranean are examined, it is seen that they often contain horrible and fictional elements. Generally, the climate and geography where the myths take place are depicted together with the landscape that creates an osmotic appearance in which the natural and supernatural elements compatible with mythos are combined. Among these, the myths of Typhon, Chimera, Pegasos, Bellerophontes, which are associated with the region and the war against the warlike Solymi, descended from Solymos, son of Ares, can be mentioned. Such a vision has been evaluated as a product of an effort to recreate anonymous myth practice, which had a strong local identity in some aspects on the Anatolian Mediterranean coasts since the Bronze Age and started to become widespread by evolving slowly with mythology as a result of increasing external contacts and interactions with the Hellenes and it is definitely not accidental. In addition to the dedication of a large number of offerings to Ares, who is mentioned in cultic terms in the region with the epithets 'supreme=megas'; 'greater=meizos' and 'hearer of prayers=epekoos', the worshipping of Mithras in the sacred rituals organized by the pirates who gathered at Olympos and the sacrifices they offered in their secret rituals are notable. It is possible to mention a series of uncanny border areas in terms of historical geographical environmental factors, bays that are easy to hide and suitable for temporary residence, dense flora suitable for shipbuilding (forests), rocky places (cliff, sea cliff and shallow reefs) and a steep mountain range starting from the seaside and rising suddenly, mysterious caves and some coastal sites associated with piracy. In the same way, in terms of ethnography people such as the Solymi, who are thought to have lived in the region during the Bronze Age, the Lycians who stand out in terms of their courage and as leaders in wars and the Pamphylians who were not afraid of aiding and abetting pirates or piracy can be noted. Etymologically, the 'Cilicans', who made piracy their profession and which has the same meaning as piracy and pirates in a regional nomenclature, can be counted. Another classification can be handled in the urbanistic sense. This is the correlation of the city named 'korykos' and the ships called 'korykaion' and the adjective 'korykaios' derived from this name with both pirates and piracy.

It is clear that sea trade become increasingly important in parallel with the developments in ship technology from the point when the first civilizations emerged in antiquity. Since the Bronze Age, the most fundamental basis of intercultural interaction in the Mediterranean has undoubtedly been sea trade. In antiquity, nearly $90 \%$ of trade was conducted via sea routes as it is today. In this respect, the phrase "wealth comes from the sea" gained widespread use in antiquity. As is the case today, the richest cities are harbour settlements established either by the sea or within easy reach of it, connected via rivers and lagoons. Such that, it is not a coincidental that when looking at modern Anatolian geography, the richest and most spectacular settlements in the context of monumental material and cultural remains are the coastal 'emporion' cities are today's centres of tourist attraction. However, intensity of the sea trade whetted the appetite of secondary powers who since mythological times and the heroic period wanted to obtain a share of this trade in one way or another, and this situation brought about the notion of plundering/piracy, one of the oldest professions that lets people exploit those working. Within this economic network, the Southwest Anatolian coast, with its location in the Eastern Mediterranean and its natural and sheltered harbours, had an inevitable geo-strategic importance for both the 
main powers and the pirates who were outside this legal power area.

As was accurately described by Cassius Dio (XXXVI. 20. 1) "Pirates always used to harass those who sailed the sea, even as brigands did those who dwelt on land. There was never a time when these practices were unknown, nor will they ever cease probably so long as human nature remains the same". The fact that characters and sailors in the verse and prose works of antiquity were asked whether they were pirates or not, and that the people who were asked the question sometimes did not deny their work and did not regard this question as an insult, caused a misunderstanding in the modern literature that piracy in antiquity was perceived as an occupation that brings glory, fame and wealth rather than one of leading a dishonourable life (Seister 2017, 14). The fact that such questions were asked mostly to those who came from the sea in antiquity is because piracy activities developed in parallel since the beginning of sea trade in the Mediterranean. In this respect, it is an incontrovertible fact that piracy was a common and accepted but was actually a hated profession in antiquity. Piracy was a part of social life like banditry in every period of antiquity and was accepted as one of the oldest and most despicable professions that lets people avoid working. When the ancient sources and decrees on piracy (epigraphical documents) as well as theatrical and literary works are carefully examined, it is seen that the ranks of the adjectives associated with piracy- treacherous, vile, ruthless, common enemy of the mankind and civilization- are mostly associated with evil. In this respect, whatever the reason may be, pirates, the common enemies of law, justice and humanity, have always been portrayed as unreliable and despicable people from whom all kinds of evil can be expected. Such that, the phrase "Pirates are like that, they don't pity anyone" in a fragment from Plautus' work entitled 'The Pirates' or 'The Blind Man', documents this process most clearly. However, as a natural consequence of the 'Law of Motion' [action/reaction], kingdoms, cities, institutions and communities victimized by pirates took measures against piracy and started to fight against them in order not to be placed in a bad situation (Arslan \& Tüner-Önen 2011, 193). Such that, it has been narrated even in the first literary works mentioning epics, such as Homer's Odyssey IX. 251-255 (also see, III. 70-74; XIV. 222-285; XVII. 424-444; Sex. Empr. Pyrrh. III. 24. 214):

\section{Polyphemos: "Strangers, who are you? Where do you sail from over the watery ways? Are you on business, or do you roam at random, like pirates who risk their lives to bring evil to others?".}

In historiography about the period of legendary kings and heroes that this situation was questioned and attitudes and precautions were taken against pirates. In Homer's texts, piracy and plunder are considered to be an informal job but not an acceptable profession which occur frequently among the people. However, when there were kings who undertook piracy, it was called a plundering expedition that did not even need to be questioned as long as it was approved and brought fame, respect and fame. In Ilias (IX. 326-329; see also lines 667-668), Achilles' boasting of having captured and plundered the twelve islands and eleven cities around Troy and its environs; in Odyssey, Odysseus' plundering expedition over Cicons [IX. 38-64] and his questions on death of the king in the scene of encountering with Agamemnon in Hades [XI. 387-408] can be given as examples of this situation. However, if those who do this are ordinary or aristocratic people who want to get rich quickly - as seen in 9 plundering movements over foreign countries by the son of Castor from among the Cretans and the plunder of Egypt [Od. XIV. 199-280]-'event and perception' are considered as piracy activity [Examples of such piratical activities and piracy attempts that resulted in, or the attempt to abduct people can be found in the Odyssey (XIV. 295-355; XV. 415-485)]. Sometimes normal citizens among the community participated in such plundering expeditions. However, when the incident was revealed, 
in the stories about it, they faced an embarrassing situation, and even saved their lives through asking influential people to mediate, stories which were kept alive in the oral cultures of the societies (Hom. Od. XVI. 424-431). This because in antiquity, piratical activities between communities were considered the most important causes of war (Hdt. I. 1-3). The activities of pirates reached such dimensions since the Bronze Age that it was emphasized by Herodotus (III. 122) and Thucydides (I. 4) that Minos, the legendary Cretan king created the first powerful navy to suppress piracy in the Mediterranean.

People want to be inspired, entertained and excited because it is of their nature and therefore they tend to believe fantastic things. When the mythological stories of the Mediterranean cultures of Ancient Anatolia are examined, it is seen that they often contain scary and imaginary elements. Generally, the climate and geography where the myths take place are depicted together with the landscape, which creates an osmotic view where natural and supernatural elements compatible with mythos are combined together. These are the subject of the myths of the killing by gods and heroes of monsters, creatures and tribes generally, such as Typhon, Bellerophontes, Pegasos, Chimera, Solymi, which damage the region, especially in the stories that have a semifantastic and semi-real appearance, where creatures from the magical and fantastic world inhabit the topography of Cilicia and Lycia. Although these folk tales, which were orally transmitted from generation to generation, changing and transforming, claim to sing of real events, they are in fact complete fabrications. What was attempted can be understood as an effort to create a new myth related to the region, through a process of blending those legends belonged to the land of fairy tales, which were fashioned to entertain and have a good time rather than educating and teaching people, with the wide range of myths of the Hellenes. Such legends may obscure a history that explains why pirates gained importance on the Mediterranean coasts of Anatolia. It would not be a wrong approach to think of them as forming a reflection of the harm caused by the uncanny nature of the region to passengers and merchants traveling by land and sea.

All ancient communities formed a local, mythological and poetic tradition regarding their origins. Mythographers, poets, and historians have expressed most of these myths in their works. These stories reveal an epic landscape associated with the region. For example, in the cave, which is located near Korykos in Cilicia, one of the sites that came into prominence with its piracy activities and is today called Cennet Sinkhole or Cennet-Cehennem, Zeus according to the myth dismembered the body of the hundred-headed dragon Typhon after defeating him and imprisoned him in this cave in Cilicia [Eustath. Hom. Il. 1. 543. Therefore, there is a cult of Zeus Korykios in the cave. There is also a belief that the cave is sacred to the Korykiai nymphs (Arslan \& Tüner Önen 2011, 196 ff. fn. 53)].

It is believed that Bellerophontes killed the monster named the Chimera, whose head was in the form of a lion, whose body was in the form of a goat, whose tail was in the form of a snake, and whose mouth was blazing, near Phaselis and Olympos with the help of the flying horse Pegasos at the request of Iobates, the Lycian king (Hom. Il. VI. lines. 179-184 ff.; see also Ovid. Met. IX. 646 ff).

Again, it is well known that Bellerophontes defeated the warlike Solymi, who damaged the borders of Lycia, and then the Amazons, fighting against them (Hom. Il. VI. 184-189; Str. XII. 8. 5-6). As a result, these deep and mysterious narratives may have contained an implicit secondary meaning. In the myths of the region during the Bronze Age, the motif of gods and heroes fighting against supernatural monsters and mythical communities that created chaos on the uncanny Mediterranean coasts of Anatolia, which were considered a home of piracy, to cleanse the region from them and bring order, seems to have been processed through these myths. 
When it comes to the eastern border regions of Lycia in a cultic sense, there are ancient sources and epigraphic documents showing that cults such as Ares, Hephaistos, Mithras come to the fore and secret sacred rites were organized in geographies where pirates and warrior peoples dwelt. Herodotus (VII. 76) mentions the Ares oracle centre of a community carrying two Lycian spears and copper headgears in the list that Xerxes recorded during the Hellas Campaign in 482/481 B.C. Despite this record provided by the father of history, our knowledge of the worship of Ares in Lycian culture was extremely limited, specific to ancient sources and modern research. However, new inscriptions were discovered on the eastern/north-eastern border of Phaselis with Termessos by the Phaselis epigraphic and historical geography teams. The fact that so many votive stelae were found during interdisciplinary research in the region in the cult area and Mizir within the boundaries of Phaselis territory indicates the importance of Ares in this region. Epigraphic documentation carried out in the area showed that dozens of offerings were presented to Ares, who was worshipped with the epithets of hearer of prayers, supreme and greater, and that Ares was a god who was loved and attracted intense attention in the region (Arslan \& Tüner- Önen 2019, 74 ff.).

In sixty-two epigraphic documents dating from the Roman Period, which were discovered in the direction of Olympos, starting from the region between Beycik and Ulupinar, which forms the border between Phaselis and Olympos, reference is made to the cult of Hephaestus (Avcu 2018, 73). Similarly, according to Plutarch (Pomp. XXIV. 5), it is stated that the pirates came together in Olympos and held secret and sacred rituals and organized festivals. There are also opinions that pirates offered sacrifices to khaos in these secret rituals and ceremonies: "In this way, the pirate stories and their lives began to become legends by being combining with divine elements. The pirates may have been aware of their bad reputation and deliberately sacrificed to khaos, making 'legend management'. As piracy activities increased in the Mediterranean, their notoriety grew and they reached a semi-mythological status". In addition, the cult of Mithras, who was one of the gods of eastern (Persian) origin and worshipped by the pirates including at Olympos, spread to the most extreme regions of the Roman Empire, especially widespread among the Roman legions, throughout antiquity.

In terms of historical geography, bandits and pirates inhabited both sides of the Taurus Mountains in the Eastern Mediterranean became a source of restlessness for Mediterranean civilizations and Romans due to environmental factors, particularly in the Hellenistic Period, when the balance of power was disrupted or uncertain. Uncanny woodlands and coasts on the borders of Cilicia and Lycia, full of rugged topography and uncertainty constituted a convenient hiding place for outlaws. These mountains, valleys and bays, which were convenient to hide in and convenient for temporary habitation, were also covered with dense forests suitable for shipbuilding. Pine varieties, mainly cedar, juniper, oak and larch, of high quality that could be used to build fully equipped ships, allowed the construction and concealment of pirate boats that were kept, speedy and close to the water in these hidden bays. The fact that some of the coves have beaches made it easier for the ships to land in a short time and hide in the forest cover beginning from the coast. In addition, the geography cut by mountain ranges running parallel and perpendicular to the coast, by cliffs and steep valleys allowed the pirates to disappear without leaving a trace in any possible attack. This because there was no road network on land for chariots and fast travel. The transportation system consisted of a complex road network of simple paths used by highlanders and shepherds, reinforced by retaining walls at the foot of the mountains.

The steep and shady mountain ranges starting from the seashore and rising inland one above 
the other and the steep sea cliffs running parallel to the shore had caves and cavities in their slopes with sometimes openings into natural bays that allowed people to live and hide temporarily. In addition, the extensions of the cliffs and sea cliffs continued under the water in the form of terraces and formed rocky shallows and shallow reefs, which were not noticeable when viewed from the sea but were located in places off the coast. In antiquity, navigation was generally in the form of coastal navigation sailing parallel to the coast and ships anchored in the bays of harbour cities were safe and usually protected by breakwaters. However, sometimes the captains, who were unaware of the underwater topography of the region, caused their ships to run aground, damaged, wrecked or even sunk in accidentally striking submerged rocks and shallow reefs. The pirates, who knew these Mediterranean waters well, established their temporary bases in caves (Korykos) near such dangerous waters by taking advantage of such information. When they were convinced that they were strong enough, they were deploying on the mountain peaks (Olympos/Musa) and headlands with panoramic view (Korakesion), which were strongly fortified by nature and human hands.

In ancient times, border regions were intercultural transition areas and came to the fore as weak points and uncanny areas in terms of their political control where the communities inhabiting these areas were generally affected by both cultures. Therefore, cities and kingdoms did not avoid taking the necessary precautions and incurring significant expenditures for the protection of border regions in antiquity, as is the case today. These could include a range of measures, from the establishment of fortified garrisons and watchtowers at strategic points in these regions, control units on the road routes, and the deployment of legions and military units nearby. However, as today, these measures were never sufficient and border regions were subject to continuous innovations and developments to increase control due to security weaknesses and loopholes. These regions have continued to come to the forefront as uncanny areas where all kinds of smuggling are intense and the crime rates are high. It should also be noted that the borders of regions and countries frequently changed as a result of political and military manoeuvring of the period. In this respect, it was not possible to record long-term control at any one point. This was also the case for the borders of Cilicia, Pamphylia, Lycia and Pisidia by the Anatolian Mediterranean. The regions on the coasts of the Eastern Mediterranean have been called by different names from time to time by different civilizations since the Bronze Age, and the boundaries of these regions have changed according to time and conditions. There were periods when piracy subsided or decreased in some regions through the attempt of powerful states to maintain order at sea and on land at times on the Eastern Mediterranean coasts. But the Mediterranean coasts of Anatolia were considered uncanny areas where pirates were hiding and piracy activities were experienced from time to time in every period in antiquity.

It can be seen that the sea trade and intercultural interaction that actuated in the Eastern Mediterranean by the Iron Age gradually gained momentum, similar to the demographic development of the region in the Age of Epics and the Orientalizing Period (ca. 900-600 B.C.), then the Great Colonization (ca. 750-550 B.C.) and Archaic (ca. 600-520 B.C.) periods. Herodotus (II. 152) states that Psammatikhos (664-610 B.C.) was the sole ruler of Egypt with the help of the Ionians and Carians, who went to sea for piracy in the VII ${ }^{\text {th }}$ century B.C. Similarly, in $c a$. 625 B.C., 12 Ionian and Doric cities initiated the establishment of the sanctuary called Hellenion in Naukratis in Egypt. In the same period, Strabo (XVII 1. 1. 18) reports that Psammetikhos allowed Miletosians to settle in a fortified place called Milesion Teikhos (Wall/Rampart of Miletosians) near Bolbitine, against the Assyrian pressure on Egypt.

By the Classical Period the Persians, the rising power of the period, put an end to the Lydian 
Kingdom in ca. 546 B.C., and they had a significant say over the Eastern Mediterranean by means of strong land forces and the Phoenician and Egyptian navies, which also included from time to time fleets from some independent Anatolian coastal and Aegean island cities. However, during the Ionian Revolt (499-494 B.C.), before and after the Battle of Lade, tyrants such as Histiaios (Hdt. VI. 5-6. 22) of Miletus and rulers such as Dionysios (Hdt. VI. 17) of Phokaia resorted to piracy to undermine Persian authority. The rapid increase in piracy especially on the Aegean coasts of Anatolia attracts attention after the Gelidonya Islands and Phaselis were accepted as the border between the Persians and the Athenians following the Peace of Callias in ca. 449/448 B.C. (Plut. Kim. XIII. 5). Such that, it is known that sea trade was not only limited to the Mediterranean, but also the Black Sea gained importance and that Athens strengthened its navy and fought against pirates in order to secure grain shipments for satisfying food requirements. It is understood from the contemporary inscriptions ( $S I G^{3}$ no 37-38) and information from ancient sources that piracy created extremely serious problems for the islands and for the coastal cities as well as for sea trade. Therefore, Pericles (Plut. Per. XVII. 1-3) sent delegates to all the Hellenic polis and island states to organize a congress in Athens after the Peace of Callias, in $c a .448 / 447$ B.C. against the pirates.

A similar situation in respect to piracy must have continued during the Peloponnesian War (431-404 B.C.). Such that both the Athenians and their allies, and the Spartans and their allies, did not hesitate to get paramilitary help from the pirates when they deem it necessary while fighting against each other (Thuk. II. 32; 69. 1; III. 51. 2; IG $\mathrm{I}^{3}$ no 65; 75). Therefore, the Athenians sent a navy consisting of six ship under the command of Melesandros to the western regions of the Eastern Mediterranean, Lycia and Caria, to damage the ships coming from Phaselis and Phoenicia and prevent them from undertaking piracy and to prevent the Peloponnesian pirates from making a base in these waters and damaging their trade fleets. However, during this expedition, Melesandros on land while in Lycia was defeated and most of the soldiers sent with him lost their lives (Thuk. II. 69. 1-2). It is possible to give dozens of examples of pirates serving in the armies of kings, generals and city states during both the Classical and Hellenistic periods. However, the fact that generals in the Classical Period and some kings in the Hellenistic Period used these pirates as mercenaries in their own navies at times allowed them to obtain a decisive position. But this is not only for some island and coastal settlements; it has also caused many cities on land to engage in piracy, either directly or indirectly, or to cooperate with the pirates and take part in these activities knowingly or unknowingly. This emerging new conjuncture has led to the emergence of two major problematic fields in the Eastern Mediterranean. The first of these is that the expressions of piracy and piracy characterize legitimate personalities in the service of the kings on the one hand; on the other hand, it is the conceptual confusion created by the fact that they are composed of independent and law-breaking people who do not recognize any authority. Moreover, characters such as Diodotos (145-138 B.C.) and Zeniketes (ca. $1^{\text {st }}$ quarter of the $\mathrm{I}^{\text {st }}$ century B.C.), who were pirates or had been a pirate at some point in their lives, took the matter further and declared their own kingdoms even if only for a short time and ruled over vast lands. This paradox can be followed with all its detail in the ancient literature.

Whereas, there are just as many documents and inscriptions that kings (Bagnall 1976, 131 ff.; Öztürk 2006, 33; Rauh 1997, 269) and generals/commanders (OGIS 552-554; Bernhardt 1972, 123 ff.; Souza 1999, 123 fn. 126) protected the cities from pirate activity particularly during the Hellenistic Period on the coasts of the Eastern Mediterranean. Nevertheless, when a generalization is made and the Mediterranean coasts of Anatolia are compared with the Aegean coasts and the Western Mediterranean, it appears to be affected as little as possible by piracy at times when there was a stable environment provided to some extent albeit for a short period of 
time when it was under Macedonian domination; during the Persian period for two centuries in the Classical Period and at the time of Alexander the Great in the Hellenistic Period (334-323 B.C.). Banditry at sea, as on land, is not generalized. However, after the untimely death of Alexander the Great in 323 B.C., the power struggles between the diadokhoi (successors) destabilized the region and the authority gap that formed created a wide space for piracy throughout the Mediterranean.

When the ancient literature and epigraphic documents are carefully examined, the reasons for the increase in piracy along the Mediterranean coasts of Anatolia during the Hellenistic Period can be listed as follows:

- The environment of instability created by internal conflicts, firstly between the successors of Alexander the Great and then between the Hellenistic kingdoms in the Eastern Mediterranean,

- The fact that Rome declared Delos an open harbour by starting to become suspicious about the loyalty of Rhodes after defeating Perseus, king of Macedonia, in ca. 168/167 B.C.,

- According to Strabo (XIV. 5.2 c. 668), the Romans became rich and started to use many slaves after they devastated Carthage and Corinth in 146 B.C.

- Deriving good profit from the sale of thousands of cheap captives and booty brought by the pirates in the open/tax-free agoras in Delos, most of whom from merchants of Roman and Hellenic origin,

- The fact that the kings of Cyprus and Egypt did not cooperate due to their hostility to the Seleucid kings against the pirate king Diodotos, who rebelled against the Seleucid kings by organizing the pirates between 145-140 B.C. and because of this situation weakening the Seleucid Kingdom,

- Similarly, since the Rhodians were at enmity with Demetrios II Nikator and Antiochus VI Epiphanes Dionysus, the fact that they refused to help the Seleucid kings in their struggle against the pirates; that even the Romans were not disturbed earlier by this situation,

- The colonial administration system in provincia Asia established by Rome on the territory of the Kingdom of Pergamon in 129 B.C., which was taken over through the bequest of Attalos III in 133 B.C.,

- The booty policy and the injustices of the Roman taxmen (publicanus) towards the Anatolian provinces and cities,

- The economic collapse caused by excessive taxation, internal conflicts and the RomanMithridatic Wars in Anatolia in the $\mathrm{I}^{\text {st }}$ century B.C.,

- The fact that in 85 B.C., the people who obtained money from Roman usurers with high compound interest to pay the 5-year penalty imposed on the provinces and cities of Asia Minor by Sulla, were unable to pay even the interest on the principal they borrowed aside from the taxes they regularly paid to the taxmen every year,

- The citizens reacted to the greed, immoral and illegal behaviour of the Roman administrators and civil servants and searching for anti-Roman freedom, and group, organization by some nobles,

- The fact that piracy was supported by the Black Sea king Mithradates VI Eupator, who fought against the Romans during the first half of the first century B.C. -until 63 B.C.and the king cooperated with the pirates in various ways and used them for his own purposes,

- Open or indirect [forced/voluntary] aid and abetting of the pirates by some Cretan settlements, cities such as Korakesion, Side, Attaleia, Korykos (those in Cilicia, Pamphyl- 
ia, Lycia, Ionia and the island of Crete),

- The fact that piracy like banditry is one of the oldest professions that lets people avoid working like others, the dream of making easy profits through piracy attracts some people.

The piracy activities on the Mediterranean coasts of Anatolia in the Hellenistic Period can be analysed through new perspectives when considered in terms of the science of ethnicity (ethnography) which makes use of material and spiritual studies of the cultures of the region, and etymology, which explains the origin of words that forms the substratum for this approach.

Pirates did not form into a nation until the Hellenistic Period. Some people from every region of the Mediterranean were engaged in piracy in different forms for different reasons throughout antiquity. However, at times, there have been cases where ethnographic naming of certain regions and urban cultures on the Eastern Mediterranean coasts has come to the fore more than others and this naming has a meaning connected with piracy. Particularly the fact that historical references to the eastern Mediterranean coasts starting from the middle of the $\mathrm{II}^{\text {nd }}$ century B.C. and throughout the first half of the $\mathrm{I}^{\text {st }}$ century B.C. remarked upon piracy activities in a consecutive and repetitive manner is important in this context. The fact that in the Hellenistic Period, the Egyptian, Seleucid and Rhodes navies, respectively retreated from the Eastern Mediterranean coasts through one by one losing their power caused the seas and the border regions of Lycia, Pamphylia and Cilicia became at risk and even caused some regions and cities to associate with this piracy. By the $\mathrm{I}^{\text {st }}$ century B.C., it was possible to mention the names of regions, islands, cities and people, which came to the fore in piracy and where piracy was mentioned, and adjectives derived from the same etymological origin. According to Appianos (Mithr. 21), since piracy first began in the mountainous areas on the southern coast of the Taurus Mountains, all the pirates in the region were called "Cilicians". Again according to Appianos (Mithr. 92), Cassius Dio (XXXVI. 20-23), Strabo (XIV. 3.2 e. 664) and Plutarch (Pomp. XXIV. 1 ff.), Cilicians and Pamphylians - together with the Eastern Lycians- were pirates themselves, or they allowed pirate ships to anchor in their harbours, built pirate ships in their shipyards, and auctioned off pirate booty in their agora. According to Strabo (XII. 7.2 c. 570), although some Pamphylian cities were not occupied by the pirates, some were in intense cooperation with them. The Pamphylians aided and abetted the Cilician pirates and connived in their illegal activities. Because the Pamphylians who had many characteristics of the Cilicians, did not hesitate to undertake piracy, nor did they allow the people on the border to live in peace even though they were settled on the southern slopes of the Taurus Mountains.

Cities such as Korakesion, Side, Phaselis and Olympos -the list can be extended-, which were notorious for their trade in ancient times, came to the fore. The reason for this must be that they adapted better to the brutal capitalism of the period than the other harbour cities and that they did not hesitate to cooperate and trade when appropriate even with the pirates. Among these, was Korakesion, known as a pirate nest and castle, standing out on the very steep rock promontory rising right by the sea. Diodotos, who took advantage of the impotence of the Seleucid kings who dominated Syrian and Cilician coasts in 145-140 B.C., rebelled against the Seleucids by organizing the pirates on the coasts of Cilicia Trakheia as the first pirate king/leader, also known as 'Tryphon'. Choosing Korakesion as his base of operations, he held control over a part of the Syrian coast, albeit for a short time, by raiding the Syrian coast and Palestinian cities from Korakesion until 138 B.C. After this date, the city drew the appearance of a city like Side, which did not hesitate to engage in piracy, sometimes openly and sometimes secretly, until Pompeius Magnus personally came to Korakesion in the summer of 67 B.C. and with the fastest 
ships of the Roman navy defeated the pirates. The fact that the people of Side traded with pirates and opened their harbours among their bad deeds was not only because they could easily obtained slaves.

Since captive exports benefited them more in terms of goods than the trade they did in their rich and wide agora, it was more attractive to them than anything else to auction off the people who were kidnapped and sold as slaves by the pirates, even knowing that they were free. Because the booty obtained by the pirates from the seas (the goods of wrecked ships) found easy buyers in the markets of Side. Thus, Side became in a short time one of the most important market places in the Mediterranean and was frequented by both pirates and traders (Str. XIV. 3. $2 \mathrm{c}$. 664). In antiquity, the people of Phaselis, who earned their living largely from sea trade, defrauded from time to time the Athenians, who were as experienced as each other, when it came to shopping, and they were even the subject of speeches and court cases of the most distinguished prolocutors of antiquity, such as Demosthenes. The period when the compulsory/voluntary relations of the city with the pirates and the pirate/king Zeniketes of Olympos were clearly revealed was in the first quarter of the $\mathrm{I}^{\text {st }}$ century B.C. Therefore, when the Roman proconsul Publius Servilius Vatia came to the region in 78 B.C., he began by ruthlessly punishing the cities of Western Pamphylia, such as Phaselis, Olympos Attaleia, which supported and cooperated with the pirates and which was under the control of Zeniketes (Ormerod 1922, 36). Then, he captured the light and elusive boats of the pirates with his heavy and well-equipped ships. He cleared the eastern shores of Lycia and Pamphylia from the pirates and destroyed the powerful cities they inhabited (Keyser 1997, $74 \mathrm{vd}$.). He seized Phaselis, one of the important harbour cities of Eastern Lycia, and Korykos, by besieging from both sea and land. Then he besieged the fortified city of Zeniketes. According to Plutarch (Pomp. XXIV. 5), the pirates came together in Olympos and organized secret, sacred rituals and festivals. The cult of Mithras with an eastern origin, was one of the gods worshiped by the pirates, and continued throughout antiquity. The king of the pirates in Lycia, which had the same name as Mount Olympus on the slopes of the Taurus Mountains. After a long siege, the city and castle fell, and Zeniketes ended his life by burning himself and his treasury.

As a result of this expedition of Servilius, the lands of Phaselis were declared as ager publicus in 78 B.C. (Atilla 2019, 2 ff.; 7). An anecdote reported by Athenaios (Deip. VIII 42) can be looked at to explain how the bad reputation of these cities spread in antiquity. When someone asked Stratonikos from Dorion, the famous harpist and humorous, who lived in the $\mathrm{IV}^{\text {th }}$ century B.C., that "Who are the most dishonest people?"; he replied as "-regionally- the Phaselis people among the Pamphylians and the people of Side among the people of the inhabited world are the most dishonest people of all". Olympos, in any case, came to the forefront as the base of Zeniketes, who took advantage of the political authority vacuum in the region and declared himself king, especially in the first quarter of the $\mathrm{I}^{\text {st }}$ century B.C. Zeniketes, with his fortified castle, which he had on the top of Musa Mount, with a panoramic view to the Pisidia mountains, along with most of the Lycia, Pamphylia and Cilicia coasts, and his strong fleet on the shores of Olympos, seemed to have a significant say in Lycian coasts before the famous Roman general Publius Servilius Vatia was sent against him with five Roman legions in 78 B.C.

Another classification can be realised within an urbanistic, topographic and etymological context. This can be seen in the correlation of the cities named 'Korykos' and possible Korakesion [In this context, the city/name of Korakesion literally means 'pirate's nest/bed'] and the adjectives derived from this name, such as 'korykaios' and 'korykaion' with pirate, pirate ship and piracy. Among these, the association of mountain/hill/rocky/cape/harbour, coast, city 
and the like (Korakesion can be included in this) with the association of the Korykos toponym in Cilicia, Pamphylia and Lycia on the Eastern Mediterranean coasts of Anatolia with piracy/pirates and naming the type of fast ship called as korykaion, of which lies low in the water, as a pirate ship is noteworthy. When the ancient sources are examined, it is seen that especially between the $\mathrm{II}^{\text {nd }}$ century and the first half of the $\mathrm{I}^{\text {st }}$ century B.C., the cities of Korykos on the Mediterranean coast were either notorious for piracy or cooperated with pirates and the characterization of the person called Korykaios 'Corycian' and of overhearing the conversations of others without revealing themselves depicted the person who aided and abetted the pirates. Moreover, comedy authors created a comic stereotypical figure called Korykaios (Corycian) in their theatrical productions who on the sly eavesdropped on the speeches of others. It is known that there were similar uses in ancient poetry and in theatrical works, and even in antiquity idioms such as: "I wonder if Corycian heard this?"; "Even Corycian can't hear this" were employed. Sometimes, comedy authors have asserted the person who listens to something was a god, based on this laconism. Dioksippos, for example, in his work Thesauros (fr. 2; 7) wrote an anecdote that "not even a Corycian hears me"; "he can only hear you if he follows you from the beginning". Vergilius (Georg. IV. 116-148) inspired verses about an old Corycian gardener. Servius (Georg. IV. 126), for example, claimed in his comment on Vergilius' Georgica that Korykaios was an old/retired Cilician pirate (Leigh 1994, 181 ff. fn. 3; Harrison 2004, 109 ff. fn. $4 ; 22-24)$. He asserted that he came to Tarentum and settled in Galaesus with the opportunity to inhabit freely in the lands bestowed by Pompeius or in the places shown to them. In this respect, just as the 'Cilician' ethnikon was once associated with pirates in ancient terminology (App. Mithr. 21; 92/93); it would not be wrong to think that the cities of Korykos located in the regions of Cilicia, Pamphylia, and Lycia, especially on the Mediterranean coasts of Anatolia and synonymous locations and in their hinterlands and the etymology of the words Korykos/Korykaios could be correlated with pirate/piracy.

By the last quarter of the $\mathrm{II}^{\text {nd }}$ century and the first half of the $\mathrm{I}^{\text {st }}$ century B.C., piracy, which had engulfed the whole of the Mediterranean like a disease, had become extremely troublesome for the cities, islands, regions, the Hellenistic kingdoms and even the Romans. Although the Romans extenuated piracy at first, they faced this piracy on the Mediterranean coasts of Anatolia and enacted a series of decrees and laws against the pirates and assigned their important commanders regionally from the last quarter of the I $^{\text {nd }}$ century B.C. However, although the Romans tried to prevent piracy rather than taking on any Hellenistic kingdom in the Hellenistic Period, they could not have a significant success against the pirates for a long time in a war without any laws, rules, or even an enemy.

They promulgated a law called lex de provinciis praetoris, also known as the lex de Cilicia Macedoniaque provinciis to block the pirates in the Mediterranean in ca. 102/101 B.C. Declaring the pirates the common enemy of the humanity, they assigned Mark Antony, nicknamed the orator, against the pirates on the Cilician coast in the same year. However, this operation of M. Antonius did not reach the expected results for the Romans. Therewith, they assigned Lucius Cornelius Sulla, the rising and talented commander of the period to Cilicia again try to eliminate the increasingly powerful piracy in the Eastern Mediterranean in ca. 95/94 B.C.; Lucius Licinius Murena, a talented commander from Sulla's legatus, to the Southern Aegean and Western Mediterranean coasts of Anatolia in 84 B.C.; Gnaeus Cornelius Dolabella and his legatus proquaestore Gaius Verres generally around Cilicia Tracheia, Lycia and Pamphylia in 80 B.C.; Publius Servilius Vatia around the borders of Lycia Pamphylia and Cilicia, between ca. 78-74 B.C.; Lucius Octavius against the tribes in the hinterland of the southern coast of the Taurus, shortly after his arrival in Cilicia in ca. 75/74 B.C. 
Then talented commanders from each other, one after another, such as (praetor) Mark Antony, [Gaius Julius Caesar in ca. 75/74 B.C. - by his own decision-] and Clodius Pulcher in 67 B.C., fought against the pirates to suppress the piracy in the Anatolian Mediterranean.

It can be stated that the Romans had difficulty in developing tactics in the war that lasted for about forty years against the pirates. The strategy used by the Romans against the pirates can be discussed under two headings. The first of these is the inductive method: to send experienced commanders to the Eastern Mediterranean coasts of Anatolia, which was considered a pirate's nest/base and constantly causing problems, in order to handle the problem in the centre -Ciliciaand sometimes focused on Cilicia, Pamphylia and Lycia- and to bring regional solutions. It is true that during these naval expeditions - such that sometimes these battles took place both at sea and on land called the piratorum officina (pirate bed) - the Romans had mostly successful results for forty years. However, this situation had the effect of each time on the pirates of pruning trees, soon piracy became stronger than it was before by spreading further, both within the region and into the surrounding regions and cities. This war, which was neither visible nor tangible, continued to arouse astonishment and fear for the Romans due to its completely different character that had never been seen before.

The second is the deductive method: the Romans changed the tactic they had repeatedly tried and failed with for forty years and began to consider the Mediterranean as a whole. They also published Senatus Consultum to fight against the pirates in all regions and districts of the Mediterranean. The draft law was introduced by Lucius Quintus Gabinius, tribunus plebis in 67 B.C., and was approved as lex Gabinia de piratis persequendis. With this law, they decided to fight all-out against the pirates in the Mediterranean by giving almost unlimited powers to Gnaeus Pompeius, one of the most famous generals of the period. Among them, the piracy expedition of Pompeius, which was the most effective and conducted over a short time (approx. three months), relieved the Eastern Mediterranean coasts of Anatolia to some extent. The fact that Pompeius came to the front of Korakesion with the fastest and most experienced fleet of his navy and defeated the Cilician pirates in a naval battle and then the effect of the general amnesty for the pirates who surrendered and laid down their weapons had big influence in this. In this way, many pirates left piracy taking advantage of a second chance offered to them and started a new life in distant corners of the Roman Empire. However, this situation does not seem to have lasted for long. Although Pompeius' expedition against the pirates and clever policies reduced piracy for a while and to some extent, piracy continued with the moral collapse in parallel with economic troubles in the Eastern Mediterranean. In 55 B.C., the Roman legate Publius Clodius Pulcher was captured by the pirates. It is tragicomic that during the civil wars that broke out in the Roman Empire shortly after Pompeius' assassination in 48 B.C. and Caesar's in 44 B.C., Pompeius' son Sextus Pompeius organized pirates under his own control and gained a significant naval power. However, Marcus Agrippa, who was both Augustus' son-in-law and admiral, hindered piracy to a large extent, by first suppressing Sextus Pompeius and then the tribes who attempted piracy in the Adriatic, such as the Cilicians. Therefore, in the Battle of Actium, which took place between Mark Antony and Octavianus on September 2, 31, there was no pirate intervention on either side. In 30 B.C., after the suicides of Mark Antony and Cleopatra, the Hellenistic kingdoms in the Mediterranean came to an end and the Eastern Mediterranean was completely under the control of the Romans. Under the 'Pax Romana' (Universal Roman Peace) of the Roman Empire, which postponed hostilities, the Mediterranean was accepted as 'Mare Nostrum' (Our Sea). If daily banditry activities on the seas for about two centuries from this date are not regarded, the Mediterranean coasts of Anatolia, like many regions of the Mediterranean, experienced more stable periods with the stable environment provided. 
In consequence, the security problem of the Mediterranean coasts of Anatolia is an issue that should be carefully investigated in terms of each period and culture of history. Sea trade, which increased in parallel with the developments in ship technology, especially from the Bronze Age onwards, seems to have whetted the appetite of secondary powers such as the pirates who wanted to share in the profits. Specific to the historical geographical location of the region, the mountainous topography and the uncanny geography of the border areas permitted illegal activities to be carried out in secret. In this respect, since the times of mythology both gods and heroes have assumed the role of defenders of order and justice against the chaotic elements in the region. A similar situation is also present in pirate types. The pirates, fed by the chaotic environment and the vacuum of authority in the region and in the Eastern Mediterranean, were able for a long time to use this situation to their advantage. In this respect, the regional nomenclature has turned into an adjective in time, and the name Cilician has been used in the same sense as pirate. It is true that kingdoms hostile to the Seleucid Kingdom, island states such as Rhodes and the Romans also played a role in the increase in this situation especially in the $\mathrm{II}^{\text {nd }}$ century B.C. After Delos was declared an open harbour in 167 B.C., deliberately or unintentionally the attractiveness of cheap slaves and the slave trade for Roman merchants and people seems to have resulted in an even greater increase in piracy. The same was valid for cities such as Side, Attaleia, Phaselis, which were fed by forced/voluntary piracy with the names of cities, persons, and boats such as Korykos, Korakesion, Korykaios or Korykaion off the Mediterranean coasts of Anatolia. From this point of view, it seems that the Mediterranean coasts of Anatolia never lost the first place in the world of antiquity during the Hellenistic Period in terms of the number of pirates per square meter of coastline.

\section{Acknowledgement}

This article is based on, and the revised version of my article "Antikçağ'da Anadolu Akdenizi'nin Öncelikli Güvenlik Sorunu: Korsanlık”. Eds. İ. H. Demircioğlu, Y. Yiğit, A. Özcan, E. Demircioğlu, C. Ünver \& G. S. Karabacak, Geçmişten Günümüze Türkiye'de Sahil ve Güvenlik. Ankara (2020) 3-30. 


\section{BIBLIOGRAPHY}

Arslan M. \& Tüner-Önen N. 2011, “Akdeniz'in Korsan Yuvaları: Kilikia, Pamphylia, Lykia ve Ionia Bölgelerindeki Korykoslar". Adalya XIV, 189-206.

Arslan M. \& Tüner-Önen N. 2019, "Phaselis Antik Kenti'nde 2018 Yılında Gerçekleştirilen Yüzey Araştırmaları ve Kazı Çalışmaları". Phaselis V, 43-83. http://dx.doi.org/10.18367/Pha.19003

Atilla D. 2019, “Phaselis Kenti Ekonomisi'nin ‘Ager Publicus' Süreci Kapsamında Değerlendirilmesi”. Phaselis V, 1-30. http://dx.doi.org/10.18367/Pha.19001

Avcu F. 2018, "Lykia Bölgesi Mezar Yazıtlarında Cezalar ve Ceza Tahsilat Kurumları". Eds. T. Kahya, A. Özdizbay, N. Tüner Önen \& M. Wilson, Uluslararası Genç Bilimciler Buluşması II: Anadolu Akdenizi Sетроzуити 04-07 Kasım 2015. İstanbul, 65-78.

Bagnall R. S. 1976, The Administration of the Ptolemaic Possessions outside Egypt. Leiden.

Bernhardt R. 1972, "Zwei Ehrenstatuen in Kaunos für L. Licinius Murena und seinen Sohn Gaius". Çev.: B. Öğün. "Kaunos’ta L. Licinius Murena ve Oğlu Gaius Şerefine Dikilmiş iki Heykel”. AAraş 17, 123-129.

Harrison S. J. 2004, “Virgil's Corycius Senex and Nicander's Georgica: Georgics 4. 116-48”. Ed. M. R. Gale, Latin Epic and Didactic Poetry. Swansea, 109-123.

$I G^{3}$ Inscriptiones Graecae.

Keyser P. T. 1997, "Sallust's Historiae, Dioskorides and the Sites of the Korykos Captured by P. Servilius Vatia". Historia 46, 64-79.

Leigh M. 1994, "Servilius on Vergil's Senex Corycius: New Evidances". Materiali e discussioni per l'analisti dei testi classici 33, 181-195.

OGIS Orientis Graeci Inscriptiones Selectae. Ed. W. Dittenberger. Vols. I-II. Leipzig 1903-1905.

Ormerod H. A. 1922, "The Campaigns of Servilius Isauricus Against the Pirates". JRS 12, 35-56.

Öztürk H. S. 2006, M.Ö. II. - M.S. IV. Yüzylllarda Likya-Pamfilya Bölgesinde Kırsal Alan Güvenliği. Yayımlanmamış Doktora Tezi, Marmara Üniversitesi, İstanbul.

Seister J. M. 2017, Antikçă̆ 'da Korsanlık. Çev.: O. Aydemir, Ankara, 2017.

SIG ${ }^{3}$ Sylloge Inscriptionum Graecarum. Ed. W. Dittenberger et al. Vols. I-IV Leipzig 1883-1924.

Souza P. De 1999, Piracy in the Graeco-Roman World. Cambridge 1999. 